\title{
Oscar Wilde and the Late-Victorian Spectacular Theatre
}

\author{
Yang Yu \\ English Department, School of Foreign Languages and Literature, Beijing Normal University, Beijing, China
}

Email address:

celavieglove@126.com

To cite this article:

Yang Yu. Oscar Wilde and the Late-Victorian Spectacular Theatre. International Journal of Literature and Arts. Vol. 8, No. 1, 2020 , pp. $23-29$. doi: $10.11648 /$ j.ijla.20200801.14

Received: January 23, 2020; Accepted: February 14, 2020; Published: February 26, 2020

\begin{abstract}
The present paper mainly focuses on the stage of archaeological authenticity in the late-Victorian spectacular theatre and Oscar Wilde's special response to this unprecedented theatrical style. The late-Victorian theatre was a place where spectacle was combined with archaeology. The spectacular effect on stage was achieved with the assistance of archaeological research. Paradoxically enough, theatre artists took great pains to find archaeological evidence for every stage scene, yet at the same time they felt entirely free to revise the text of the playwright and to replace words with images. Oscar Wilde did not understand the spectacular nature of his age until the early 1890s. His early journalistic essay "Shakespeare on Scenery" and its extended version "Shakespeare and Stage Costume" stressed the realistic effect created by the archaeological stage, while in "Truth of Masks", the final version of "Shakespeare on Scenery", Wilde radically reversed his original argument and turned to assert the importance of illusion by changing certain expressions of the text. The controversial views contained in the several versions of the text hinted at Wilde's own ambiguous attitude towards the historical spectacles on stage. Yet the novel The Picture of Dorian Gray, published in 1891, reflected Wilde's growing understanding of the visual spectacles on stage. For Wilde, as represented by Dorian Gray in the novel, the spectacular stage provided the only proper site for visual concentration of his age. Dorian's excessive love of stage image also accounted partially for Wilde's advocacy of the predominance of appearance in his aesthetics.
\end{abstract}

Keywords: Wilde, Spectacularization, Archaeological Authenticity, Dorian Gray

\section{Introduction}

Oscar Wilde is one of the important dramatists in the late-Victorian period. On the whole, Wilde's dramatic career can be divided into three phases. His early dramatic attempts - Vera; or, The Nihilists (1881) and The Duchess of Padua (1883) - failed to attract the attention of both dramatic critics and theatre managers. In the second phase, that is, from around 1884 to 1891 , Wilde did not engage himself directly in dramatic writing, but he was always keeping a keen eye on the West End theatricals. He was well aware of the new fashions on stage and had intimate relationships with several important managers and actors. The third phase lasted only three years. It started from 1892 when Wilde achieved his first theatrical success with social comedy Lady Windermere's Fan and ended in 1895 when the performance of his last finished play The Importance of Being Earnest was interrupted by sudden imprisonment. In recent theatrical studies of Wilde, critics have noticed the interplay between
Wilde's theatrical career and literary creation. In his article "The Critic as Mime: Wilde's Theatrical Performance", rather than taking Wilde totally as an anti-mimetic artist, Nidesh Lawtoo interprets Wilde's life imitating art as a recuperation of the "dramatic conception of mimesis". In his view, the dramatic mimesis "displays not only a visual, aesthetic representation but also, and more important, a bodily theatrical impersonation in which actors serve as paradigmatic examples of the power of artistic types to give form to human lives" [1]. In what follows, I will further explore the paradoxical nature of Wilde's criticism by tracing the changing process of one of his dramatic reviews during the 1880 s. Wilde did not write plays during this period, but the reviewing practices in the journalistic world provided him a precious chance to evaluate the contemporary stage fashion from different and even contradictory perspectives. Then I will explore in detail the most conspicuous fashion of the theatre, the archaeological presentation and reflect upon the spectacular nature of this presentation. In the last part, I will explain how Wilde obtained an insight into these spectacles 
created on stage by analyzing Dorian Gray's obsession with Sybil's creation of stage illusions. I will show that Dorian's love for Sibyl is, in essence, a love for sheer artificiality and thorough publicity.

\section{2. "The Truth of Masks" and the Archaeological Stage Presentation}

This section tends to analyze one of Wilde's dramatic reviews concerned with the archaeological stage presentation - The Truth of Masks. In the essay, Wilde insightfully noticed that both theatre managers and the audience of his time had an insatiable curiosity about the visual exhibition on stage. Besides, the lengthy publishing process of the article and the controversial views contained in the several revisions of the text revealed that Wilde struggled to bring together the contemporary theatrical fashion and his aesthetic ideals during the $1880 \mathrm{~s}$.

In summer 1891, Oscar Wilde wrote a letter to Jules Cantel, the French translator of Intentions, saying:

With great pleasure I approve that M. J. Cantel translate Intentions into French. The right of authorization belongs to me exclusively. Only I do not want him to translate the last essay, "The Truth of Masks"; I do not like it any more. Instead one can put the essay that appeared last February in the Fortnightly Review, "The Soul of Man," which contains part of my aesthetics. [2]

Wilde published Intentions in English in the year 1891. In this English version, Wilde included four articles he had written during the 1880s: "The Decay of Lying," "Pen, Pencil and Poison," "The Critic as Artist," and "The Truth of Masks." Among them, the first three essays epitomized Wilde's aesthetic beliefs: the ideas of life imitating art, of truth as a matter of style, and of the multiplicity of personality - all made Intentions a calculated mixture of sensation and scholarship. The last essay "The Truth of Masks" seemed to be an exception in both theme and content despite Wilde's strenuous revision of many expressions of the text. In Sondeep Kandora's words, the essay concluded the collection "by seemingly rejecting the aesthetic propositions that preceded it" [3].

"The Truth of Masks" was initially published in The Nineteenth Century in May 1885 with the title "Shakespeare and Stage Costume," and the earlier form of "Shakespeare and Stage Costume" was a short essay named "Shakespeare on Scenery" appearing in the Dramatic Review on March $14^{\text {th }}$, 1885. In these two early versions, Wilde paid tribute to the archaeological employment of costume and scenery in the theatre as a mode of intensifying dramatic situation. He wrote in "Shakespeare on Scenery": "To talk of the passion of play being hidden by the paint, and of sentiment being killed by scenery, is mere emptiness and folly of words" [4]. In "Shakespeare and Stage Costume," Wilde used the revival of Shakespearean plays in his time to exemplify the realistic effects produced by archaeology in the design of stage costume. He argued:
For what is the use to the stage of that archaeology which has suddenly become the bete noire of the critics, but that it, and it alone, can give us the architecture and apparel suitable to the time in which the action in the play passes? It enables us to see a Greek dressed like a Greek, and an Italian like an Italian; to enjoy the arcades of Venice and the balconies of Verona; and, if the play deals with any of the great eras in our country's history, to contemplate the age in its proper attire, and the king in his habit as he lived. [5]

In this passage, Wilde stressed the realistic effect produced on stage under the assistance of archaeology. Wilde argued that archaeology alone could get the audience acquainted with a past event in its visual form. In his view archaeology was "not merely a science for the antiquarian" but a means by which dramatists could "touch the dry dust of antiquity into the breath and beauty of life" [5]. Throughout the essay, Wilde repeated the idea of the importance of archaeology for dramatic presentation, as he put it: "Perfect accuracy of detail, for the sake of perfect illusion, is necessary for us" [5]. At the time when the essay was published, Wilde worked as a journalistic reviewer mainly for Pall Mall Gazette and The Dramatic Review. Nearly all the articles Wilde wrote for The Dramatic Review were concerned with the present-day stage performances, which showed that he was very familiar with the archaeological fashion on the contemporary stage. Besides, according to one recent study, Wilde also went to the exhibitions in archaeology during this period [6]. Wilde wrote in "Shakespeare and Stage Costume": "the most lovely scenes recently produced on our stage have been those which were distinguished by perfect accuracy" [5]. And then he listed four theatre managers: Mr. and Mrs. Bancroft, Mr. Irving and Mr. Barrett. They were the most prominent advocates of the archaeological stage in the late Victorian period.

In 1891 for the publication of Intentions, Wilde radically revised "Shakespeare and Stage Costume." The essay was renamed as "The Truth of Masks - A Note on Illusion." The new title possessed a certain provocative charm, indicating a superficial and illusionary quality. As regards to the text, Wilde reversed his original argument that archaeology was indispensable for the realistic stage presentation. He changed the word "realism" or its cognates to "illusion," whenever they appeared in the text. Lawrance Danson is the first critic taking notice of this subtle revision. He notices that the sentence "Costume is one of the essential factors of the means which a realistic dramatist has at his disposal" in "Shakespeare and Stage Costume" is changed into "Costume is one of the essential factors of the means which a true illusionist has at his disposal" in "The Truth of Masks"; Shakespeare's "relations to realism" becomes his "relations to the great art of illusion" [7]. There are many similar changes of words in "The Truth of Masks." Through these alterations, realism is banished from the new text. Under the same narrative structure, with the same examples and historical materials, Wilde transforms a text celebrating "modern realistic spirit" into a text speaking the "truth of masks." The two essays provide a startling example of how 
Wilde plays with language by turning a text into an opposite of itself.

Wilde himself seemed to have reservations for these alternations. At the end of "The Truth of Masks," Wilde added a new paragraph, stating his views on this new essay:

Not that I agree with everything that I have said in this essay. There is much with which I entirely disagree. The essay simply represents an artistic standpoint, and in aesthetic criticism attitude is everything. For in art there is no such thing as a universal truth. A Truth in art is that whose contradictory is also true. [8]

This passage is usually taken as Wilde's exhibition of his unique paradoxical style in an argument. However, in the light of the transforming process that the text of the essay has experienced, I would rather suggest that this ending paragraph looks more like self-defense than a proud display of intellectual power. From 1885 when the short essay "Shakespeare on Scenery" first appeared on The Dramatic Review to 1891 when "The Truth of Masks" was included in Intentions, Wilde underwent a subtle transformation. In the beginning, he was conforming himself to the archaeological fashion on stage, which celebrated the realistic effect it produced, and later, he was trying to give this archaeological presentation a new meaning by changing certain expressions of the text when he found it in contradiction with his aesthetic thoughts. However, Wilde himself was quite uncertain about these practices of compromise. Therefore, in his letter to the French translator Jules Cantel, as cited at the very beginning of this section, Wilde expressed his reluctance to publish "The Truth of Masks" together with the other three essays.

\section{The "Spectacularization" of the Stage}

Wilde's continuous interest in the archaeological stage presentation draws our attention to this particular theatrical style. From the mid-nineteenth century, the "spectacular effect," namely, to create a visual spectacle on stage with splendid processions, sumptuous banquets and grand pictorial scenes, preoccupied many theatre managers and thus became one important principle for theatrical practice. For the production of such a spectacular environment, the theatre managers improved the stage effect mainly through an accurate historical presentation, and this historically accurate stage eventually became one of the most distinctive features of the nineteenth-century theatrical culture. In "The Truth of Masks" Wilde makes the point rather clear: "[T] hat desire for archaeological accuracy... has distinguished the great actors of our age" [8]. With the development of archaeology during the mid-nineteenth century, a mania for archaeological authenticity on costume and settings swept over the major theatres in the West End of London. In order to represent the grand scene of a historical event, the theatre managers did thorough researches in the museums and galleries. Some of them even traveled abroad to do archaeological research for scenic accuracy. The following part will offer an detailed introduction of the stage of archaeological authenticity by analyzing the theatrical production of Henry Irving, one of the most famous theatre managers in the late nineteenth century. In the late nineteenth century, one of the most important theatrical reforms was that the long run system had been accepted as a common practice. In 1860 theatre manager Dion Boucicault produced the play The Colleen Bawn specifically for a long run. It played for 230 nights at the Adelphi, and Baucicault claimed that by this run and his subsequent touring performances, he had created "a new order of theatrical affairs" with more than $\$ 200,000$ clear profit - "the largest, I believe, even taken up to that date" [9]. In Players and Performances in the Victorian Theatre George Taylor emphasizes the discrepancy existing between the representations of accuracy and the old repertoire system: "It was a meticulous, restrained and modern style, suited to the repertoire of Tom Taylor and Dion Boucicault, but unsuited to the improvisational hurlyburly of the stock theatre tradition" [9]. As Taylor suggests in his comment, the traditional repertoire/stock system was already not suitable for the new archaeological style in stage presentation. With the introduction of the long run, the theatre finally found an effective way for their archaeological presentation, either in a business or artistic sense. Under the long run system, the manager was encouraged to stage a play in a complicated archaeological style, for a well-prepared play could be performed as frequently as possible: several weeks, several months and even several years. Therefore, the manager could get enough time and financial reward for the production. Upon this point, Michael R. Booth comments: "There was only one way of paying for and profiting from productions of this magnitude of expenditure and that was, of course, the long run" [10].

Along with the introduction of the long run management, a specialized acting team was gradually formed among the actors. The new system permitted a careful study of the roles and systematic training for the performance. This ultimately led to the specialization of the acting profession, which accordingly brought about enormous profits to the theatre. For instance, in the Haymarket Theatre, the Bancrofts developed a consistent "house-style" and became "so financially successful that they could retire in 1885 when Squire Bancroft was only forty-four. When Bancroft died in 1926 he left over £174,000" [9]. In this process of specialization, actors were categorized into different groups for different roles, and as a result, the actor that could best employ his voice, posture, and personality soon rose to the prominent position and became the star performer in the theatre. This was bound to lead to a frantic admiration of theatrical stars among theatregoers. A contemporary theatregoer John Drinkwater once recalled his excitement on seeing a famous theatrical star:

When I was sixteen I ran from my office at closing time and stood for two hours or more in a queue outside a Birmingham theatre holding nine pence with which to pay for early door admission to the gallery.... After furtive and vain efforts to squeeze myself into some corner of vantage, I somehow climbed up the back wall, swarmed along a beam 
on my stomach, and lay the entire evening on a six-inch accumulation of dust, peering down from the roof on to a stage that seemed to be a mile away. [9]

The star actor for whom, as Drinkwater described, the theatregoers showed such a great passion, was Henry Irving - the most brilliant and influential actor-manager in the late-Victorian London. Irving could be taken as the most convincing example of specialization in performance. As an experienced actor, Irving developed a bizarre sound by distorting his natural voice, as a contemporary reviewer described: "His voice seems sometimes artificial treble in quality and to be jerked out with effort" [11]. With his peculiar voice, Irving impressed the pubic greatly.

As a successful actor-manager, Henry Irving was most famous for his stage of archaeological authenticity. Either artistically or economically, it was Irving that finally arrived at the peak of theatrical archaeological presentation. In 1888 while preparing a specialized archaeological presentation in costumes and properties for the play Macbeth, Charles Cattermole, Irving's designer, spent much time "searching the British and South Kensington Museum for authority for every article of costume, weapon, furniture, and domestic utensil down to every nail and button and blade" [12]. At last, Cattermole "designed 408 dresses altogether, including 165 for soldiers... and 80 for the traditional Flight of Witches" [13]. Macbeth ran for 151 performances, and after watching the performance, French director Andre' Antoine was greatly impressed by the "incomparable" mise en scène, particularly the lighting "of which we had hardly any idea in France" [12]. Irving paid much attention to the artistic beauty of the stage. In his opinion, the "first duty of anyone who mounts a piece is to produce a beautiful and pleasing effect" [14]. As Irving himself stated, he tried to keep a balance between historical authenticity and artistic beauty in stage presentation. Irving transformed the stage into a picture. For Irving, the archaeological display was no more than an absolute staging principle, but merely a representational skill. In this sense, both Irving's statements and artistic practices signify that as the stage of archaeological authenticity reached its summit in Irving's hand, it also began to decline.

Seen from the example presented above, this unique theatrical style was closely connected with the revival of Shakespearean plays in the Victorian period. But it seems to be a paradoxical phenomenon: in the revival of Shakespearean plays, theatre managers were, on the one hand, trying to find for every stage scene archaeological evidence; but on the other hand, they appeared free of any limitations in using the text of the playwright. Many acts of the original script as a whole were often deleted, and in other cases, a new scene was added just to create an archaeological spectacle. While staging Henry $V$, theatre manager Charles Kean invented a scene of Henry V returning to London, which could not be found in Shakespeare's play. When his another revival of Shakespearean play The Winter's Tale was put on stage, the journal Literary Gazette criticized the production as "a series of striking dramatic tableaux strung upon Shakespeare's text" [15]. The archaeological stage seemed to have little to do with the original text, and where the text was regarded, it often functioned as evidence of archaeological achievement. This intentional disregard of the text echoed the general trend in the late-Victorian theatre of taking scenery as the prominent attraction to the audience. Scenery did not simply refer to the stage background or setting in its usual meaning, but the visual spectacle created with the assistance of archaeology. On stage, an actor was attractive not for his power to depict a specific role or to express a special emotion, but for his ability to integrate himself into the scenery. In view of this special phenomenon, Booth employs the term "spectacular theatre" to refer exclusively to this theatrical presentation in the late Victorian period. Booth points out that in the late-Victorian theatre, the "pace of production, the particular uses of mass, color, light, and costume, the technique of the actor - all these elements of spectacle really have no parallel on the Western dramatic stage of today" [13]. In the spectacular theatre, costume and scenery became, for the first time, the main attraction, while actors served only as corporal carriers of the archaeological spectacle. The late Victorian actor John Ryder once complained to the famous actress Ellen Terry: "D'ye suppose he employed me for my powers as an actor? Not a bit of it! He employed me for my damned archaeological figure!" [9] With the assistance of archaeology, the latest scientific method of the time, the theatre managers sought to "make of the actor's physical instrument a visual spectacle" [16], and to produce an illusionary "real" past on the stage; they strove to let historical figures "speak for themselves, to make the witness of the facts vouch for their truth.... in so doing, they give us a vivid and accurate picture of the times when they lived" [15].

As thus envisaged, the charm of the archaeological presentation lied in the special sensational experience it provided for both actors and theatregoers. This sensational effect was ensured through a successful representation of a picturesque spectacle. This explained the way a historical event was attended in a spectacular theatre. It was an interpretation of detail: these men of theatre were capable of peeling off concrete parts from a historical continuum. To them, history was neither the abstract knowledge of the past, nor a chronological record of historical events. Rather, it was the formal manifestation of a concrete past scene. Their prudent choice of every costume and property, gorgeous decoration of the stage and elaborate design of the facial expressions and gestures - all of these painstaking preparations and meticulous arrangements revealed how fervidly Victorian theatricals pay attention to the formal beauty of the stage.

\section{Dorian Gray and the Visual Concentration in the Spectacular Theatre}

In that early article on the stage of archaeological authenticity "Shakespeare on Scenery," Wilde said: "Theatrical audiences are far more impressed by what they 
look at than by what they listen to" [4]. As Wilde observed, the theatrical audience of his time had an insatiable curiosity about the visual exhibition on stage, and under the assistance of archaeology, the theatre artists managed to satisfy this need. The following part will show that for Wilde, as represented by Dorian Gray in the novel The Picture of Dorian Gray, the spectacular stage provided the only proper site for a visual concentration of his time. Dorian's excessive love of stage images was, in essence, a love for spectacles.

Wilde's continuous fascination with the theatre is preconditioned by a realization that the theatre is the only place that can realize the "exhibition complex" of the age to its fullest extent. In The Picture of Dorian Gray, Wilde expresses the idea in a rather subtle way. In the novel, the greatest romance of Dorian Gray happens in "an absurd little theatre" [17]. One night, Dorian Gray, the extremely beautiful young man, was wandering aimlessly in a street of London. He came across a little theatre unknown to him. Driven by an unspeakable desire, Dorian went into the theatre and paid for a stage-box for the performance of Romeo and Juliet. In the beginning, he felt annoyed by the idea that Shakespeare's romantic tragedy was performed in such a shabby theatre. When he saw Juliet played by a girl whose voice "was very low at first, with deep mellow notes that seemed to fall singly upon one's ear," and then "became a little louder, and sounded like a flute or a distant hautboy," Dorian felt that he met "the loveliest thing" he had ever seen in his life. He could not help but exclaim to his friend Lord Henry Wotton: "But an actress! How different an actress is! Harry! Why didn't you tell me that the only thing worth loving is an actress?" [17] The actress Dorian admired so much was Sibyl Vane. From then on, every night Dorian went to see her act. The theatre became the place where he thought that he could touch the marvelous with his finger. In his description of Sibyl's beauty, what Dorian admired most was her distinct Greek face, as he said: "But Juliet! Harry, imagine a girl, hardly seventeen years of age, with a little, flowerlike face, a small Greek head with plaited coils of dark-brown hair, eyes that were violet wells of passion, lips that were like the petals of a rose" [17]. Dorian's appreciation of Sibyl's Greek beauty embodied Wilde's own idea of the beauties on the contemporary stage. In Wilde's rapt attention to the special Grecian charm, we detect Wilde's fascination with the stage spectacle of his time.

As is well known, during the years he spent in London, Wilde was fascinated by several actresses who were most famous for their Greek beauty. Lillie Langtry was an actress with "classic features - the grave low forehead, the exquisitely arched brow; the noble chiseling of the mouth, shaped as if it were the mouthpiece of an instrument of music; the supreme and splendid curve of the cheek; the augustly pillared throat which bears it all" [18]. Overwhelmed by Langtry's consummate beauty, Wilde compared her to Helen of Troy: "Yes, it was for such ladies that Troy was destroyed, and well might Troy be destroyed for such a woman" [18]. Another actress for whom Wilde also showed a devoted admiration was Ellen Terry. In September 1880, Wilde sent to Terry a privately printed copy of his first play Vera; or, the Nihilists, bound in dark red leather. Accompanying the play was a complimentary letter, in which Wilde wrote: "Perhaps someday I shall be fortunate enough to write something worthy of your playing. We all miss you so much, and are so jealous that the provinces should see you in all the great parts you are playing before we do" [2]. On January $3^{\text {rd }}$ 1881, the day when Ellen Terry was about to play the leading role in Tennyson's verse play The Cup, Wilde sent her flowers and wrote a note of encouragement: "I write to wish you every success tonight. You could not do anything that would not be a mirror of the highest artistic beauty" [2]. After watching the performance, Wilde wrote a sonnet for Ellen Terry titled "Camma," as it was Terry's part in the play. In the poem, Wilde writes:

As one who poring on a Grecian urn Scans the fair shapes some Attic hand hath made, God with slim goddess, goodly man with maid, And for their beauty's sake is loth to turn and face the obvious day, must I not yearn, For many a secret moon of indolent bliss, When in the midmost shrine of Artemis I see thee standing, antique-limbed, and stern? [19]

Rather than describing the performance of the actress, the sonnet displays Wilde's particular concern with the Greek female image standing motionless on stage, as if absorbed into something profound. Terry's statuesque figure, together with other Greek decorations - the Grecian urn and the godly sculptures, constitutes a picturesque scene. According to the Athenaeum reviewer, the play was notably a "dramatic spectacle," in which Ellen Terry's statuesque grace "had never before been so happily and fully exhibited" [20]. The Pall Mall Gazette commented likewise: "To the grace, distinction, and breadth of style of Miss Terry as Camma the success of the representation is chiefly attributable. Wearing with exquisite grace the Grecian costume, Miss Terry gave the early scenes all the charm of which they are capable" [20].

Seen from the praises of the contemporary press, Wilde's admiration for both Lillie Langtry and Ellen Terry had its root within the broader framework of the theatre's growing fascination with the spectacular representation of Greek classicism. As Gail Marshall notices, the demand "for Classicism on the English stage was well established in the 1880s" [20]. Here, Marshall refers to the fashion in the late-Victorian theatre which generated manifestations on stage of a sculpture-like Greek beauty with the actress's body. In his article "The Stage" published on Academy in 1883, Frederick Wedmore said of those "to whom a story, if it deals with Ancient Greece, appeals as matter to be reverenced" [20]. The theatrical method for the presentation of ancient Greece was to dress the performers, mainly the actresses, in draperies. Like the stage of archaeological authenticity, the chief value of these stage representations was "as spectacle rather than as effective drama" [20]. According to Louise Jopling, an actress involved in the play Helena in Troas, was instructed by the stage designer Edward Godwin to "drape, and seat, half a dozen figures in the same attitudes as those on the frieze of the Parthenon. The poor things had to remain 
without moving during the whole time the play was in progress! They were attired in unbleached calico draperies, which simulated the white marble, just tinged with age, wonderfully well" [20]. The actresses on stage had been thoroughly submerged into the creation of spectacular effects of Greek pictorialism.

It is within such a general theatrical fascination for spectacles that Dorian Gray's obsession with Sibyl Vane's beauty can be understood. With her little "Greek head," Sibyl epitomized the Grecian charm of the actress on stage. She was a performer for visual spectacles by instinct, as Dorian Gray claimed: "To-night she is Imogen.... and tomorrow night she will be Juliet" [17]. Dorian was infatuated with Sibyl's changing images on the stage, which showed anything but her own personality. For Dorian, Sibyl was "all the great heroines of the world in one" because she was "more than an individual" [17]. On stage the actress was completely transformed into a form of spectacular exhibition. Only in the illusionary world that Sibyl created could Dorian find a love through which he became master of his own desire and passion. Dorian proclaimed to Lord Henry Wotton "I love her, and I must make her love me.... I want to make Romeo jealous. I want the dead lovers of the world to hear our laughter and grow sad. I want a breath of our passion to stir their dust into consciousness, to wake their ashes into pain" [17]. Dorian poured out his passionate love for Sibyl, for the actress in her spectacular display symbolized the vital force of life. When Sibyl came on stage in her boy's clothes, Dorian noticed the special exquisiteness of the actress: "She wore a moss-colored velvet jerkin with cinnamon sleeves, slim, brown, cross-gartered hose, a dainty little green cap with a hawk's feather caught in a jewel, and a hooded cloak lined with dull red. She had never seemed to me more exquisite" [17]. Dorian was completely lost in the pleasant intoxication; a tender kiss on Sibyl's trembling lip made him feel that all his life "had been narrowed to one perfect point of rose-colored joy" [17]. For the moment, Dorian "forgot that [he] was in London and in the nineteenth century, feeling that he "was away with his love in a forest that no man had ever seen" [17]. Through Sibyl, Dorian experienced the peculiar pleasure that could only be provided by the spectacular exhibition. She created the spectacular world with her body and soul. Dorian's affection for Sibyl was thus a love for spectacles.

Sibyl misunderstood Dorian's indulgence for spectacles, represented by her multi-personalities, as a manifestation of love for herself. She was inspired to leave the stage illusions and return to reality: "Dorian, Dorian, before I knew you, acting was the one reality of my life. It was only in the theatre that I lived.... You came - oh, my beautiful love! and you freed my soul from prison. You taught me what reality really is" [17]. Like a beam of light, Dorian's passionate "love" was shining on Sibyl's life. For the first time in her life, Sibyl had a feeling of her own. Subtle changes happened to this poor little girl: "A rose shook in her blood and shadowed her cheeks. Quick breath parted the petals of her lips. They trembled. Some southern wind of passion swept over her and stirred the dainty folds of her dress. 'I love him,' she said simply" [17]. Inspired by Dorian's admiration, Sibyl began to examine the world around her - the world of theatre where she had been living. Everything became different. What she found out was a spectacular stage composed of "hollowness," "the sham," "silliness," and "emptiness." Feeling her sincere love for Dorian, the "Prince Charming" in her mind, Sibyl could no longer bear the vulgar reality unfolding before her eyes. She felt loathing for the stage spectacles which had deprived her of real human feelings and desired to fly away with her lover from this spectacular world.

No doubt Dorian Gray refused to share with Sibyl her the joy of transformation. Lover of excessive spectacles, Dorian could not accept an actress that had lost her ability for the creation of stage illusions. Seeing the new Sibyl perform on stage in an unnatural manner, Dorian felt thoroughly despaired. He cried to Sibyl: "You have killed my love. You used to stir my imagination. Now you don't even stir my curiosity. You simply produce no effect" [17]. The spectacular "shadows" of the theatre of which Sibyl grew sick was for Dorian the only wonderland where he could store his love and passion. At last, Sibyl Vane committed suicide, and Dorian Gray, stepping out of the theatre, again receded into the dim city of London. Having lost the "charismatic spectacle" [21] of Sibyl Vane, Dorian became an aimless wanderer of life again. So he did many things but had no mind for anyone of them. With no visual concentration in the outside world, Dorian got tired of himself and his life. Drifting here and there, he could not find a substitution for the spectacular world of the theatre embodied in the actress Sibyl Vane, on which he had once rested his gaze and pinned his hope for art.

\section{Conclusion}

In my exploration of the connection between Oscar Wilde and the spectacular theatre, Wilde was not simply a popular dramatist who achieved enormous success on the London stage with several comedies. Rather, he was identified as a notorious public aesthete who succeeded in cutting a smart figure in the public sphere and thus acutely sensed the age's obsession with visual exhibition of various kinds. Against this historical background, the theatre, with its special archaeological stage presentation, appeared to be the ideal place for both Wilde and other Victorians to display and appreciate visual spectacles. In The Picture of Dorian Gray, Wilde expressed the idea in an implicit way. Dorian was in love with the stage images of the actress Sibyl Vane rather than Sibyl herself. In Dorian's eyes, the greatest attraction of the actress lied in her sheer publicity and absolute artificiality. Sibyl was "absolutely and entirely divine" because she "kn [ew] nothing of life" [17]. Her beauty on stage could be compared to a work of art, as Dorian exclaimed to his friend, painter Basil Hallward: "She had all the delicate grace of that Tanagra figurine that you have in your studio, Basil. Her hair clustered round her face like dark leaves round a pale rose" 
[17]. For Dorian, Sibyl always possesseed a unique allure. She did not have a personality of her own but existed entirely in representations.

In The Society of the Spectacle, Guy Debord conceives the world where life is nothing other than a mere representation as the world of the spectacle. In his argument, wherever representation becomes independent of reality, "the spectacle reestablishes its rule" [22]. In this sense, the spectacle assumes a social character which enables it to invert life and thus becomes the "autonomous movement of non-life" [22]. In both theatre artists' relentless pursuit of historical illusions on stage and Wilde's continuous interest in these illusions, we detect this trend towards "non-life." It is true that theatre artists created a visual spectacle with the assistance of archaeological research, but the spectacle turned out to be a force independent of its producer, as Thomas Richards comments: "Display, extravagance, and excess survived-but less for the sake of those who staged the spectacle than for the sake of the spectacle itself' [23]. For Wilde, as represented by Dorian Gray in particular, the spectacular stage provided the only proper site for visual concentration. Dorian's excessive love of stage image also accounted partially for Wilde's advocacy of the predominance of appearance in his aesthetics, as Lord Henry proclaimed in the novel: "It is only shallow people who do not judge by appearances. The true mystery of the world is the visible, not the invisible" [17].

\section{References}

[1] Lawtoo, Nidesh. "The Critic as Mime: Wilde's Theoretical Performance" symplokē, 26. 1-2 (2017): 307-328.

[2] Wilde, Oscar. The Complete Letters of Oscar Wilde. Ed. Merlin Holland and Rupert Hart-Davis. London: Fourth Estate, 2000: 96-487.

[3] Sondeep Kandora. "Rereading Oscar Wild's intentions for 'The Importance of Doing Nothing'" Nineteen-Century Prose, Vol. 43, Spring/Fall 2016: 385-402.

[4] Wilde, Oscar. Selected Journalism. Oxford: Oxford UP, 2004: 44-46.

[5] Wilde, Oscar. "Shakespeare and Stage Costume." Nineteenth Century, January — June 1885: 800-818.

[6] Thornton, Amara. "Tis the Season: annual exhibition in archaeology" Petrie Museum of Egyptian Archaeology: Characters and Collections. Ed. Alice Stevenson. London: UCL Press, 2015: 84-87.
[7] Danson, Lawrence. Wilde's Intentions: The Artist in His Criticism. Oxford: Clarendon, 1999: 68.

[8] Wilde, Oscar. The Complete Works of Oscar Wilde. New York: Barnes \& Noble Books, 1994: 1060-1078.

[9] Taylor, George. Players and Performances in the Victorian Theatre. Manchester: Manchester UP, 1989: 9-101.

[10] Booth, Michael R. Theatre in the Victorian Age. Cambridge: Cambridge UP, 1991: 35.

[11] Mullin, Donald. Victorian Actors and Actresses in Review: A Dictionary of Contemporary Views of Representative British and American Actors and Actresses, 1837-1901. Ed. Donald Mullin. Westport: Greenwood, 1983: 253.

[12] Hughes, Alan. Henry Irving, Shakespearean. Cambridge: Cambridge UP, 1981: 17-89.

[13] Booth, Michael R. Victorian Spectacular Theatre: 1850-1910. Boston: Routledge, 1981: 47-160.

[14] Finkel, Alicia. Romantic Stages: Set and Costume Design in Victorian England. Jefferson, NC: McFarland, 1996: 83.

[15] Schoch, Richard W. Shakespeare's Victorian Stage: Performing History in the Theatre of Charles Kean. Cambridge: Cambridge UP, 1998: 51-99.

[16] Storm, William. "Impression Henry Irving: The Performance in the Portrait by Jules Bastien-Lepage." Victorian Studies: An Interdisciplinary Journal of Social, Political, and Cultural Studies 46.3 (2004): 399-423.

[17] Wilde, Oscar. The Complete Works of Oscar Wilde. Ed. Bobby Fong, et al. vol. 3 Oxford: Oxford UP, 2000: 186-243.

[18] Ellmann, Richard. Oscar Wilde. New York: Vintage, 1988: $110-111$.

[19] Wilde, Oscar. The Complete Works of Oscar Wilde. Ed. Bobby Fong, et al. vol. 1 Oxford: Oxford UP, 2000: 152.

[20] Marshall, Gail. Actress on the Victorian Stage. Cambridge: Cambridge UP, 1998: 97-101.

[21] Nunokawa, Jeff. Tame Passions of Wilde. Prince: on: Princeton UP, 2003: 147.

[22] Debord, Guy. The Society of the Spectacle. Trans. Donald Nicholson-Smith. New York: Zone, 1994: 12-17.

[23] Richards, Thomas. The Commodity Culture of Victorian England: Advertising and Spectacle 1851-1914. Stanford: Stanford UP, 1990: 55-56. 